\author{
Doris Bösch \\ Mona Pache \\ Ronald Simon \\ Peter Schraml \\ Katharina Glatz \\ Martina Mirlacher \\ Josef Flammer \\ Guido Sauter \\ Peter Meyer
}

\section{Expression and amplification of therapeutic target genes in retinoblastoma}

Received: 7 November 2004

Revised: 11 June 2004

Accepted: 17 August 2004

Published online: 10 November 2004

(C) Springer-Verlag 2004

D. Bösch · M. Pache - J. Flammer ·

P. Meyer ( $)$

Universitäts-Augenklinik Basel,

Mittlere Strasse 91, 4056 Basel,

Switzerland

e-mail: pemeyer@uhbs.ch

Tel.: +41-61-2658643

Fax: +41-61-2658747

D. Bösch · R. Simon · P. Schraml •

K. Glatz · M. Mirlacher · G. Sauter .

P. Meyer

Institut für Pathologie,

Universität Basel,

Basel, Switzerland

M. Pache

Universitäts-Augenklinik Freiburg,

Freiburg, Germany

\begin{abstract}
Purpose: We set out to evaluate alterations of the therapeutic target genes KIT (CD 117), EGFR, and HER-2 in human retinoblastoma. Methods: Ninety-five formalin-fixed, paraffin-embedded retinoblastomas were brought into a tissue microarray (TMA) format. Immunohistochemistry was performed to analyze the expression of CD117, EGFR, and HER-2. Fluorescence in situ hybridization (FISH) was utilized for detection of EGFR amplifications. Three tumors with strong CD117 positivity were sequenced for KIT exon 11 mutations. Results: Detectable CD117 expression was seen in $19 \%$ of all interpretable cases.

Sequence analysis of the three tumors with the strongest CD117 expression revealed no mutations. EGFR was
\end{abstract}

positive in $14 \%$ of all cases. No EGFR amplification was observed by FISH, however. All tumors were negative for HER-2 expression. Conclusions: Our data suggest that selected cases of retinoblastoma may be candidates for anti-EGFR and imatinib mesylate (STI571) therapy.

\section{Introduction}

Retinoblastoma occurs in $1 / 20,000$ newborns and is the most common ocular malignancy that causes blindness in children. Retinoblastoma is fatal if untreated, but over 95\% of the patients survive if treated before the tumor spreads outside the eye [38]. The primary goal of retinoblastoma treatment is to save the patient's life. At the same time it is intended to save the eye and vision whenever possible. Therefore, enucleation is performed only in advanced disease with no hope of preserving useful vision. Other methods, such as external-beam radiotherapy, plaque radiotherapy, laser photocoagulation, cryotherapy, and thermotherapy, are used with the intention of preserving the eye in the case of small, organ-confined tumors [36]. In some instances, tumor reduction chemotherapy prior to local treatment can be critical for avoiding enucleation or external-beam radiotherapy [5, 37].

Once a tumor has spread through the sclera into the orbit, systemic chemotherapy is the only treatment option [11]. Carboplatin, vincristine, etoposide, and cyclophosphamide have been suggested as cytotoxic therapy regimens but the success rate has been disappointing $[8,27$, 40]. Recently, a new category of cytotoxic reagents have been brought to market. These drugs specifically target individual genes that are overexpressed or otherwise altered in cancer cells. Trastuzumab (Herceptin), a humanized antibody targeting the HER-2 gene, which is overexpressed in about $20 \%$ of breast cancers, was the first example of this new drug category. Trastuzumab has been successfully used in a fraction of breast cancers [3, 7]. STI571 (Glivec), a small-molecule kinase inhibitor, 
weas initially developed to target the BCR-ABL fusion gene product in chronic myeloid leukemia [10]. Subsequently this drug turned out also to inhibit KIT (CD117), thus showing strong effects in patients with gastrointestinal stroma tumors (GIST), a tumor entity known for a particularly high level of KIT protein expression [24]. The epidermal growth factor receptor (EGFR) is another receptor gene for which more than ten different anticancer drugs have been developed [2, 4].

All these therapeutic target genes appear to be overexpressed in various tumor types. It can therefore be anticipated that the new drugs listed above will eventually prove useful in many different tumor entities. In order to collect information on their potential utility in retinoblastoma, we analyzed a series of 95 retinoblastomas for alterations of HER-2, CD117, and EGFR genes.

\section{Material and methods}

Tumors/tissue microarray construction

Formalin-fixed, paraffin-embedded tissue from 95 retinoblastomas obtained in the years 1985-2001 was collected from the archives of the institutes of ophthalmopathology and pathology, University of Basel, Switzerland. The use of archival material was approved by the local ethics commission. All cases were classified according to the pTNM classification (UJCC 5th edn, 1997). The series included 29 males, 56 females, and nine patients of unknown sex. The mean age was 3.33 years (range $0.25-24$ ). The pT stage was pT1 in 1, pT2 in 3 , pT3 in 33, and pT4 in 58 cases.

Tissue microarray (TMA) construction was as previously described [9]. In brief, tissue cylinders with a diameter of $0.6 \mathrm{~mm}$ were punched from representative tumor areas of each "donor" tissue block using a semi-automatic tissue arraying instrument and brought into a recipient paraffin block. The TMA blocks were constructed in two copies, each containing two to three samples of the 95 retinoblastomas. Four-micrometer sections of the resulting TMA blocks were transferred to an adhesive-coated slide system (Instrumedics, Hackensack, NJ, USA) [(Fig. 1)].

\section{Immunohistochemistry}

The HercepTest (Dako, Glostrup, Denmark) was used for HER-2 protein analysis. Staining, control, and interpretation of the results were carried out according to the manufacturer's instructions.

The anti-CD117 antibody from Dako (A4502) was used for CD117 analysis. In a comparison of multiple antibodies, A4502 had yielded the highest specificity, the strongest specific staining, and the least background (Philip Went, personal communication). A4502 was applied at a dilution of 1:300 at room temperature for $2.5 \mathrm{~h}$, after $3 \mathrm{~min}$ pressure cooking in $10 \mathrm{mM}$ sodium citrate buffer ( $\mathrm{pH}$ 6.0) for antigen retrieval. Endogenous peroxidase was blocked using $0.3 \%$ hydrogen peroxidase diluted in methanol for $30 \mathrm{~min}$. A standard $\mathrm{ABC}$ technique (Vector $\mathrm{ABC}$ kit) using $\mathrm{DAB}$ for visualization was used. For specificity control, a preabsorption of the antibody was performed (CD117 peptide stock solution, Neomarkers PP1518). This antigen matches the sequence of the epitope recognized by the polyclonal antibody of Dako. A case of GIST was used as a positive control (Fig. 2).

The monoclonal antibody EGFR (1:50; Triton Biosciences, Alameda, CA, USA) was used for EGFR analysis. The optimal titer for EGFR was defined as the dilution that gave clearly identifiable

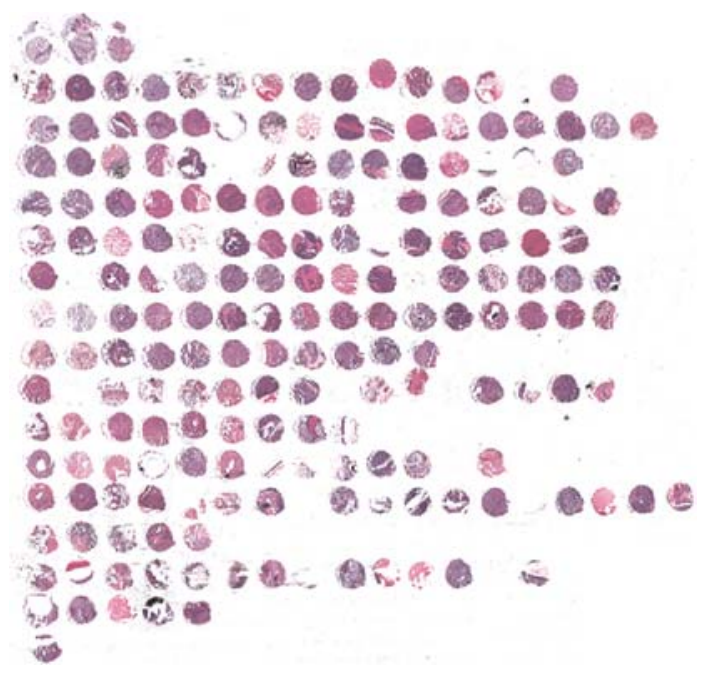

Fig. 1 Retinoblastoma tissue microarray (TMA): overview of an H\&E-stained TMA section

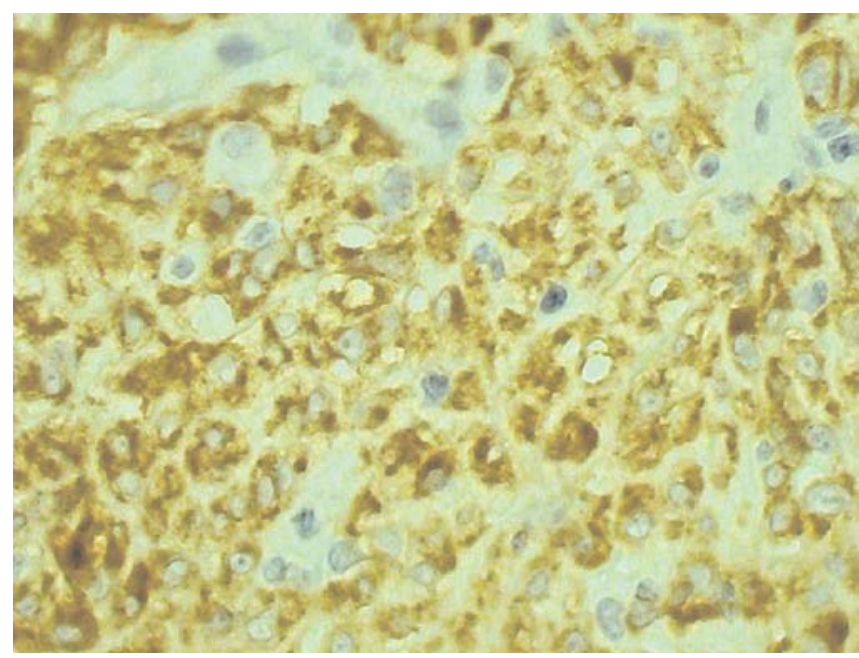

Fig. 2 Gastrointestinal stromal tumor served as a positive control (40-fold magnification)

membrane staining and negligible background on human placental samples. The optimal protocol used an antibody dilution of 1:50, antigen retrieval and an avidin-biotin complex immunoperoxidase procedure (ABC Elite, Vector, Burlingame, CA, USA) for visualization of antibody binding. Human placenta and a slide where the primary antibody was omitted served as positive and negative controls.

The proportion of cells positive for CD117 and EGFR was estimated and the staining intensity was semi-quantitatively recorded as $1+, 2+$, or $3+$. Only membranous staining was considered. For statistical analysis, the staining results were categorized into four groups. Tumors without any staining were considered negative. Tumors with $1+$ staining intensity in $<60 \%$ of cells and $2+$ intensity in $<30 \%$ of cells were considered weakly positive. Tumors with $1+$ staining intensity in $\geq 60 \%, 2+$ intensity in $30 \% \leq x>80 \%$, or $3+$ intensity in $<30 \%$ of cells were considered moderately positive. Tumors with $2+$ intensity in $\geq 80 \%$ or $3+$ intensity in $\geq 30 \%$ of cells were considered strongly positive. 

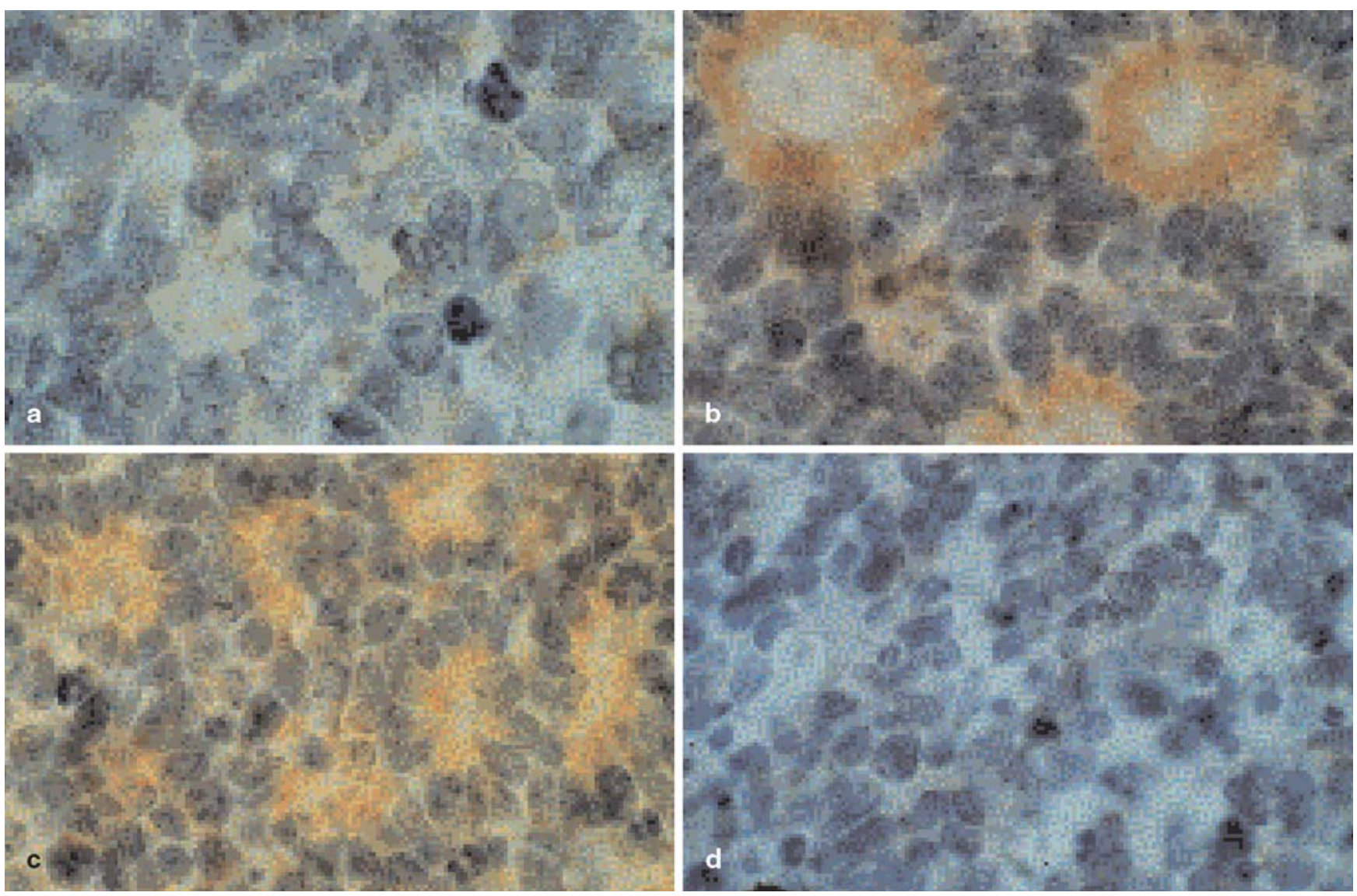

Fig. 3 Example of three tumors positive for CD-117 (KIT). a Weak positivity; b moderate positivity; c strong positivity; d example of a tumor negative for CD-117 (KIT) (100-fold magnification)

\section{Sequence analysis for CD117}

Three retinoblastomas showing intense CD117 staining were selected for KIT mutation analysis. Deparaffinizing of the formalinfixed tissues and DNA extraction was performed according to protocols of Qiagen (Qiagen, Basel, Switzerland). Exon 11 was amplified using a semi-nested PCR approach, and was sequenced directly using Big Dye Terminators Cycle Sequencing Ready Reaction Kit (Applied Biosystems, Foster City, CA, USA). Sequence products were analyzed on an ABI Prism 310 Genetic Analyzer (Applied Biosystems).

\section{Statistical analysis}

Chi-square statistic was used for comparisons of gene alteration frequencies between tumors of different stages or grades.

\section{Results}

CD117

Immunostaining could be evaluated in 73 of the 95 cases (77\%). Analysis failures were due to either lack of tissue on the TMA section or lack of vital tumor cells in the arrayed samples. Positive CD117 staining was seen in 14 of 73 interpretable tumors (19.2\%) (Fig. 3). The staining was membranous in all cases. Positivity was weak in four, moderate in seven, and strong in three cases. There were no differences in frequency or intensity of KIT staining between tumors of different stages or grades. Sequencing of exon 11 did not reveal KIT mutations in the three tumors with strong immunohistochemical KIT positivity.

\section{EGFR}

Immunostaining could be evaluated in 80 of 95 cases $(84 \%)$. Positive staining was seen in 11 of 80 interpretable tumors $(14 \%)$. The staining was membranous in all cases (Fig. 4). Positivity was weak in two, moderate in two, and strong in seven cases. The FISH analysis yielded interpretable data in $50 \%$ of tumors. None of them showed gene amplification according to our definition (Fig. 5). 

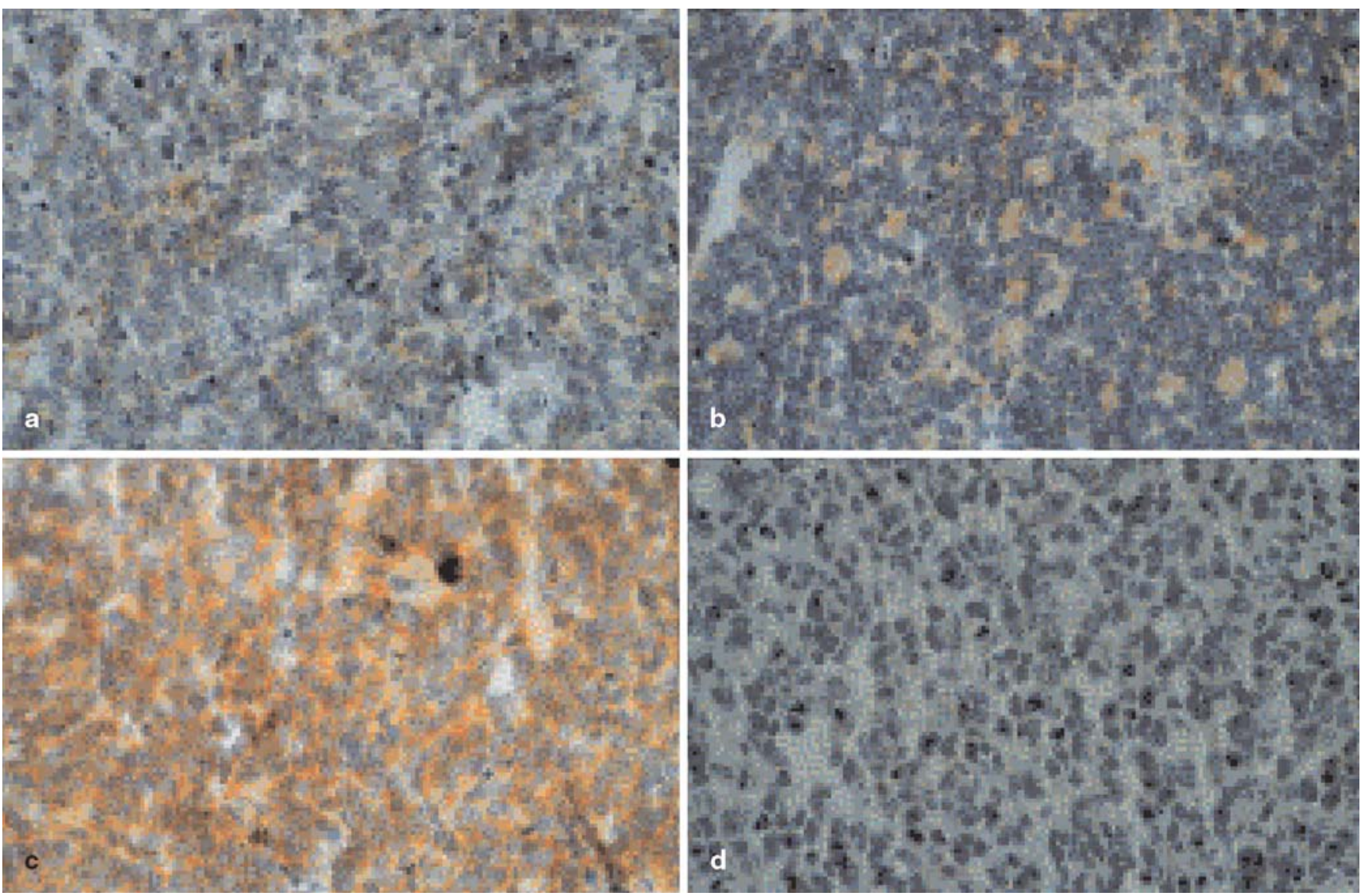

Fig. 4 Examples of EGFR-positive tumors. a Weak positivity; b moderate positivity; c strong positivity; $\mathbf{d}$ example of a tumor negative for EGFR (40-fold magnification)

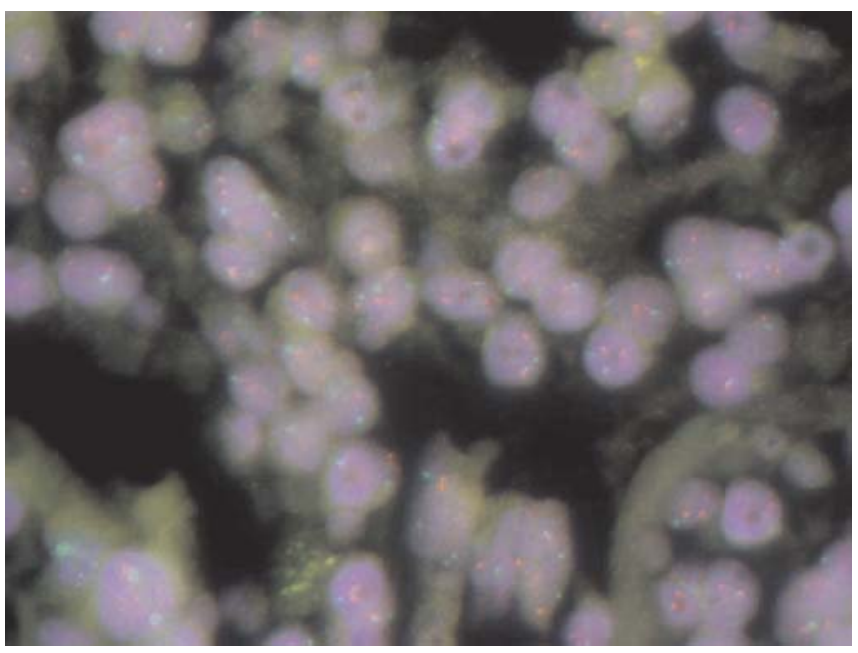

Fig. 5 Example of an EGFR-positive tumor: FISH analysis showed no gene amplification (100-fold magnification)

\section{HER-2}

Immunostaining could be evaluated in 80 of 95 cases (84.2\%). None of the tumors showed positive HER-2 staining (Fig. 6). For this reason, no HER-2 FISH analysis was attempted.

\section{Discussion}

A TMA was used to evaluate gene alterations in a series of 95 retinoblastomas. In this method, a number of minute tissue samples (diameter $0.6 \mathrm{~mm}$ ) are analyzed on one microscope glass slide. It is evident that focal gene alterations are not always detected in a TMA setting. However, this perceived disadvantage seems to be compensated by the high number of tumors that can be included in a TMA study and maximal standardization of the analyses [16, 32, 33]. In fact, all tissue samples on one TMA section are processed under absolutely identical conditions. Numerous studies have shown that representative information can be obtained in TMA analyses [9, 26]. For example, the known frequencies of amplifica- 


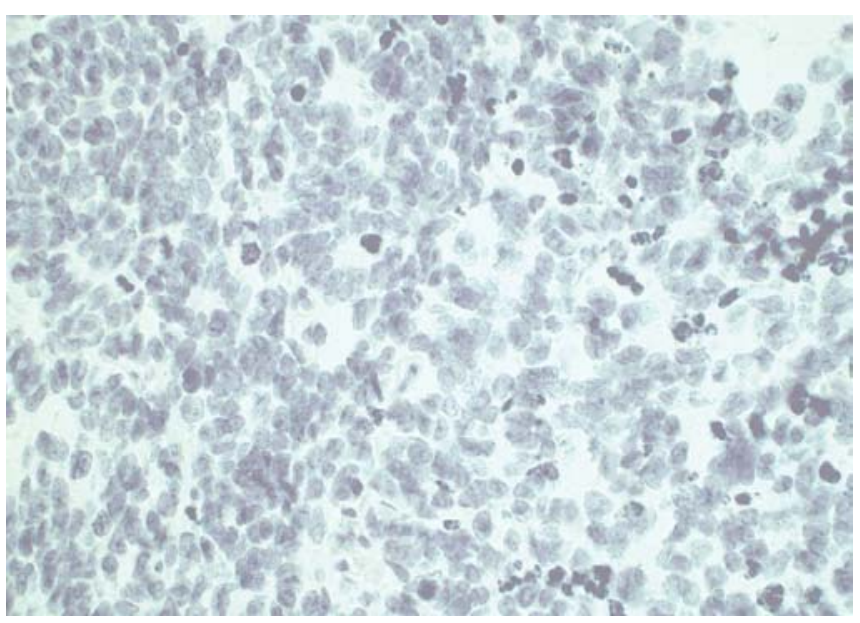

Fig. 6 A tumor negative for HER-2 (40-fold magnification)

tions of various genes have been confirmed in TMA studies in various tumor types [17, 35]. Other TMA projects have confirmed the previously established prognostic impact of molecular markers, such as the expression of estrogen receptor, progesterone receptor and $\mathrm{p} 53$ in breast cancer [39] or of the Ki-67 labeling index in bladder cancer [28].

In this study, gene alterations of KIT, EGFR and HER2 were analyzed because their gene products have been successfully utilized as molecular targets for new anticancer drugs. Detection of alterations of these genes in retinoblastoma would raise hope that these drugs could also be utilized for systemic therapy of retinoblastoma.

EGFR overexpression has previously been reported to occur in various tumor types, especially in brain tumors and squamous cell carcinomas [1, 6, 18, 34]. Our data show that retinoblastoma belongs to the group of tumor entities with a marked frequency of EGFR overexpression. EGFR positivity was detected in $14 \%$ of our tumors. However, no association with either tumor stage or grade was observed, suggesting that EGFR alterations do not play a role in retinoblastoma progression. It will be interesting to see whether anti-EGFR therapies will be successful in retinoblastoma.
KIT expression was found at considerable frequency in our tumors: almost $20 \%$ of them showed KIT positivity. This raises the possibility that imatinib mesylate could be a therapeutic option in these tumors, as this drug has a strong effect against KIT-positive GIST [23, 29, 30]. In GIST, several groups have studied the clinical implication of the KIT mutation status of exon 11 and were able to establish a possible relationship between these mutations and malignant behavior. The activating mutations lead into ligand-independent activation of the tyrosine kinase of KIT and have been shown to have a transforming effect in vitro $[19,20]$.

Several studies are now ongoing to see whether imatinib mesylate has a beneficial effect on other KIT-positive tumors. Our data suggest that retinoblastomas could be included in these studies. However, the lack of mutations in exon 11 found in our sequenced strongly positive tumors may argue against a favorable response to imatinib mesylate. Recent studies have shown that the response to STI571 preferentially occurs in tumors with activating KIT mutations [15]. This does not, however, rule out a potential beneficial effect of imatinib mesylate in retinoblastoma, since other authors have reported at least some therapeutic effect in KIT-positive tumors expressing the wild-type protein $[14,21]$. Further studies testing this hypothesis, e.g., on retinoblastoma cell lines, are desirable.

HER-2 alterations have not been previously examined in retinoblastoma. Our data show that HER-2 alterations occur extremely infrequently or not at all in this tumor type. This observation is not surprising since HER-2 expression is known to be rare in comparable tumor entities, such as brain tumors, skin, melanomas, and other small round-cell malignancies [12, 13, 22, 31]. Accordingly, trastuzumab (Herceptin) does not appear to have a therapeutic effect on retinoblastoma.

Taken together, our data show that EGFR overexpression and KIT alterations can occur in retinoblastoma. Further studies are required to see whether drugs targeting these genes have beneficial effects in selected patients with retinoblastoma. Furthermore, our study demonstrates how expediently molecular targets can be analyzed on TMAs.

\section{References}

1. Arteaga CL (2002) Epidermal growth factor receptor dependence in human tumors: more than just expression? Oncologist 7:31-39

2. Arteaga CL, Johnson DH (2001) Tyrosine kinase inhibitors-ZD1839 (Iressa). Curr Opin Oncol 13:491-498
3. Arteaga CL, Moulder SL, Yakes FM (2002) HER (erbB) tyrosine kinase inhibitors in the treatment of breast cancer. Semin Oncol 29:4-10

4. Barton J, Blackledge G, Wakeling A (2001) Growth factors and their receptors: new targets for prostate cancer therapy. Urology 58:114-122
5. Beck MN, Balmer A, Dessing C, Pica A, Munier F (2000) First-line chemotherapy with local treatment can prevent external-beam irradiation and enucleation in low-stage intraocular retinoblastoma. J Clin Oncol 18:2881-2887

6. Blackledge G, Averbuch S, Kay A, Barton J (2000) Anti-EGF receptor therapy. Prostate Cancer Prostatic Dis 3:296-302 
7. Bozzetti C, Nizzoli R, Guazzi A, Flora M, Bassano C, Crafa P, Naldi N, Cascinu S (2002) HER-2/neu amplification detected by fluorescence in situ hybridization in fine needle aspirates from primary breast cancer. Ann Oncol 13:1398-1403

8. Brichard B, De Bruycker JJ, De Potter P, Neven B, Vermylen C, Cornu G (2002) Combined chemotherapy and local treatment in the management of intraocular retinoblastoma. Med Pediatr Oncol 38:411-415

9. Bubendorf L, Kononen J, Koivisto P, Schraml P, Moch H, Gasser TC, Willi N, Mihatsch MJ, Sauter G, Kallioniemi OP (1999) Survey of gene amplifications during prostate cancer progression by high-throughput fluorescence in situ hybridization on tissue microarrays. Cancer Res 59:803-806

10. Buchdunger E, Cioffi CL, Law N, Stover D, Ohno-Jones S, Druker BJ, Lydon NB (2000) Abl protein-tyrosine kinase inhibitor STI571 inhibits in vitro signal transduction mediated by c-kit and platelet-derived growth factor receptors. J Pharmacol Exp Ther 295:139-145

11. Finger PT, Czechonska G, Demirci H, Rausen A (1999) Chemotherapy for retinoblastoma: a current topic. Drugs 58:983-996

12. Fink-Puches R, Pilarski P, Schmidbauer U, Kerl H, Soyer HP (2001) No evidence for c-erbB-2 overexpression in cutaneous melanoma. Anticancer Res 21:2793-2795

13. Forseen SE, Potti A, Koka V, Koch M, Fraiman G, Levitt R (2002) Identification and relationship of HER-2/neu overexpression to short-term mortality in primary malignant brain tumors. Anticancer Res 22:1599-1602

14. Heinrich MC, Griffith DJ, Druker BJ, Wait CL, Ott KA, Zigler AJ (2000) Inhibition of c-kit receptor tyrosine kinase activity by STI 571, a selective tyrosine kinase inhibitor. Blood 96:925-932

15. Joensuu H, Fletcher C, Dimitrijevic S, Silberman S, Roberts P, Demetri G (2002) Management of malignant gastrointestinal stromal tumours. Lancet Oncol 3:655-664

16. Kallioniemi A, Kallioniemi OP, Sudar D, Rutovitz D, Gray JW, Waldman F, Pinkel D (1992) Comparative genomic hybridization for molecular cytogenetic analysis of solid tumors. Science 258:818-821

17. Kononen J, Bubendorf L, Kallioniemi A, Barlund M, Schraml P, Leighton S, Torhorst J, Mihatsch MJ, Sauter G, Kallioniemi OP (1998) Tissue microarrays for high-throughput molecular profiling of tumor specimens. Nat Med 4:844-847
18. Kuttan NA, Bhakthan NM (1997) Epidermal growth factor receptor (EGFR) in oral squamous cell carcinomas: overexpression, localization and therapeutic implications. Indian J Dent Res 8:9-18

19. Lasota J, Jasinski M, Sarlomo-Rikala M, Miettinen M (1999) Mutations in exon 11 of c-Kit occur preferentially in malignant versus benign gastrointestinal stromal tumors and do not occur in leiomyomas or leiomyosarcomas. Am J Pathol 154:53-60

20. Lasota J, Wozniak A, Sarlomo-Rikala M, Rys J, Kordek R, Nassar A, Sobin LH, Miettinen M (2000) Mutations in exons 9 and 13 of KIT gene are rare events in gastrointestinal stromal tumors. A study of 200 cases. Am J Pathol 157:1091-1095

21. Ma Y, Zeng S, Metcalfe DD, Akin C, Dimitrijevic S, Butterfield JH, McMahon G, Longley BJ (2002) The c-KIT mutation causing human mastocytosis is resistant to STI571 and other KIT kinase inhibitors; kinases with enzymatic site mutations show different inhibitor sensitivity profiles than wildtype kinases and those with regulatorytype mutations. Blood 99:1741-1744

22. Micke P, Hengstler JG, Ros R, Bittinger F, Metz T, Gebhard S, Beeh KM, Oesch F, Buhl R (2001) c-erbB-2 expression in small-cell lung cancer is associated with poor prognosis. Int J Cancer 92:474479

23. Miettinen M, Lasota J (2001) Gastrointestinal stromal tumors-definition, clinical, histological, immunohistochemical, and molecular genetic features and differential diagnosis. Virchows Arch 438:1-12

24. Miettinen M, Sarlomo-Rikala M, Lasota J (1998) Gastrointestinal stromal tumours. Ann Chir Gynaecol 87:278281

25. Moch H, Sauter G, Gasser TC, Bubendorf L, Richter J, Presti JC Jr, Waldman FM, Mihatsch MJ (1998) EGF-r gene copy number changes in renal cell carcinoma detected by fluorescence in situ hybridization. J Pathol 184:424-429

26. Moch H, Schraml P, Bubendorf L, Mirlacher M, Kononen J, Gasser T, Mihatsch MJ, Kallioniemi OP, Sauter G (1999) High-throughput tissue microarray analysis to evaluate genes uncovered by cDNA microarray screening in renal cell carcinoma. Am J Pathol 154:981-986

27. Murphree AL, Villablanca JG, Deegan WF III, Sato JK, Malogolowkin M, Fisher A, Parker R, Reed E, Gomer CJ (1996) Chemotherapy plus local treatment in the management of intraocular retinoblastoma. Arch Ophthalmol 114:1348-1356
28. Nocito A, Bubendorf L, Maria Tinner E, Suess K, Wagner U, Forster T, Kononen J, Fijan A, Bruderer J, Schmid U, Ackermann D, Maurer R, Alund G, Knonagel H, Rist M, Anabitarte M, Hering F, Hardmeier T, Schoenenberger AJ, Flury R, Jager P, Luc Fehr J, Schraml P, Moch H, Mihatsch MJ, Gasser T, Sauter G (2001) Microarrays of bladder cancer tissue are highly representative of proliferation index and histological grade. J Pathol 194:349357

29. van Oosterom AT, Judson I, Verweij J, Stroobants S, di Paola ED, Dimitrijevic S, Martens M, Webb A, Sciot R, Van Glabbeke M, Silberman S, Nielsen OS (2001) Safety and efficacy of imatinib (STI571) in metastatic gastrointestinal stromal tumours: a phase I study. Lancet 358:1421-1423

30. van Oosterom AT, Judson IR, Verweij J, Stroobants S, Dumez H, di Paola DE, Sciot R, Van Glabbeke M, Dimitrijevic S, Nielsen OS (2002) Update of phase I study of imatinib (STI571) in advanced soft tissue sarcomas and gastrointestinal stromal tumors: a report of the EORTC Soft Tissue and Bone Sarcoma Group. Eur J Cancer 38:S83-S87

31. Persons DL, Arber DA, Sosman JA, Borelli KA, Slovak ML (2000) Amplification and overexpression of HER-2/ neu are uncommon in advanced stage melanoma. Anticancer Res 20:19651968

32. Sauter G, Moch H, Moore D, Carroll P, Kerschmann R, Chew K, Mihatsch MJ, Gudat F, Waldman F (1993) Heterogeneity of erbB-2 gene amplification in bladder cancer. Cancer Res 53:2199_ 2203

33. Sauter G, Moch H, Gasser TC, Mihatsch MJ, Waldman FM (1995) Heterogeneity of chromosome 17 and erbB-2 gene copy number in primary and metastatic bladder cancer. Cytometry $21: 40-46$

34. Scholes AG, Hagan S, Hiscott P, Damato BE, Grierson I (2001) Overexpression of epidermal growth factor receptor restricted to macrophages in uveal melanoma. Arch Ophthalmol 119:373-377

35. Schraml P, Kononen J, Bubendorf L, Moch H, Bissig H, Nocito A, Mihatsch MJ, Kallioniemi OP, Sauter G (1999) Tissue microarrays for gene amplification surveys in many different tumor types. Clin Cancer Res 5:1966-1975

36. Shields CL, Shields JA (1999) Recent developments in the management of retinoblastoma. J Pediatr Ophthalmol Strabismus 36:8-18 (quiz 35-16) 
37. Shields CL, Honavar SG, Meadows AT, Shields JA, Demirci H, Naduvilath TJ (2002) Chemoreduction for unilateral retinoblastoma. Arch Ophthalmol 120:1653-1658

38. Tamboli A, Podgor MJ, Horm JW (1990) The incidence of retinoblastoma in the United States: 1974 through

1985. Arch Ophthalmol 108:128-132
39. Torhorst J, Bucher C, Kononen J, Haas P, Zuber M, Kochli OR, Mross F, Dieterich H, Moch H, Mihatsch M,

Kallioniemi OP, Sauter G (2001) Tissue microarrays for rapid linking of molecular changes to clinical endpoints. Am J Pathol 159:2249-2256
40. Wilson MW, Czechonska G, Finger PT, Rausen A, Hooper ME, Haik BG (2001) Chemotherapy for eye cancer. Surv Ophthalmol 45:416-444 